\title{
Anthranilic acids from isatin: an efficient, versatile and environmentally friendly method
}

\author{
GABRIEL F. RIO, BÁRBARA V. SILVA, \\ SABRINA T. MARTINEZ and ANGELO C. PINTO \\ Instituto de Química-CT, Universidade Federal do Rio de Janeiro/UFRJ, Avenida Athos da Silveira Ramos, \\ 149, Bloco A, $7^{\circ}$ andar, Cidade Universitária, 21941-909 Rio de Janeiro, RJ, Brasil
}

Manuscript received on June 10, 2014; accepted for publication on November 4, 2014

\begin{abstract}
This paper describes the preparation of a series of 16 anthranilic acids in yields ranging from 51 to $97 \%$, by treating the isatins with $\mathrm{NaOH}$ and $\mathrm{H}_{2} \mathrm{O}_{2}$. Independently of the nature of the substituent on the aromatic ring, the reactions were complete in $15 \mathrm{~min}$ at room temperature, whereas those of isatins containing a substituent on the nitrogen atom required longer reaction time for completion (45 min) under the same reaction conditions.
\end{abstract}

Key words: isatin, anthranilic acid, 2-aminobenzoic acid, isatin oxidation.

\section{INTRODUCTION}

Anthranilic acid or 2-aminobenzoic acid (1 - Fig. 1) is an intermediate metabolite for the production of the neurotransmitter serotonin (Mendoza et al. 2008). For playing a significant role in human lactation it is called vitamin L1, where the "L" stands for lactation, although it is not officially recognized as a vitamin (Wang and Okabe 2005).

Anthranilic acid was first described by Carl Julius Fritzsche (1808-1871) in the early XIX century when it was accidentally obtained from the degradation of indigo. Since then anthranilic acid has been used in the textile industry as a raw material for the production of dyes (Wiklund and Bergman 2006). It is target of various chemical transformations, such as alkylation or acylation reactions at the amino group, esterification and coupling with amines

Correspondence to: Bárbara V. Silva

E-mail: barbara.iq@gmail.com at the carboxyl group and electrophilic aromatic substitution reactions (Wiklund and Bergman 2006, Naik et al. 2004, Hosangadi and Dave 1996, Mahiwal et al. 2012, Chaudhuri et al. 2007). Anthranilic acid and derivatives have applications in various sectors, including the food and perfumery industries, and are used in the syntheses of bioactive molecules (Wiklund and Bergman 2006). It is noteworthy that Ponstan $^{\circledR}$ (mefenamic acid, used to relieve pain and inflammation) and Diurisa ${ }^{\circledR}$ (furosemide + amiloride hydrochloride, a diuretic association) have the anthranilic core. According to the literature, anthranilic acid exhibits anticancer, antimicrobial, insecticide, antiviral and anti-inflammatory activities (Huang et al. 2006, Lahm et al. 2007, Yadav and Krishnan 1998, Nittoli et al. 2007, Pajor and Sun 2013).

A few methods are available for the synthesis of unsubstituted anthranilic acid. Although yields are high, the reaction conditions are often severe 
and/or require the use of expensive reagents which need careful handling ( $\mathrm{Xu}$ and Wolf 2009, Guin et al. 2007, Pandarus et al. 2011).

Substituted anthranilic acids can be obtained from the electrophilic aromatic substitution of anthranilic acid, or from the reaction of substituted isatins with $\mathrm{NaOH}$ and $\mathrm{H}_{2} \mathrm{O}_{2}$ (Popp 1975, Da Silva et al. 2001, Lisowski et al. 2000, Gérard et al. 2005). Although this method was described by Mayer and Schulze in 1925 (Mayer and Schulze 1925), no systematic study of this reaction has appeared in the literature. Herein we describe our studies of this reaction, starting from a number of isatins and varying the nature and position of the substituents in the aromatic ring or in the $\mathrm{N}-\mathrm{H}$ group.

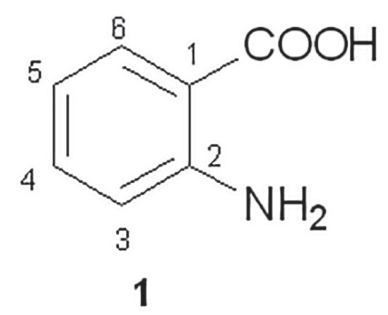

Figure 1 - Structure of anthranilic acid (1).

\section{RESULTS AND DISCUSSION}

All anthranilic acids were obtained in a single step from the reactions of substituted isatins with sodium hydroxide $(\mathrm{NaOH} 5 \% \mathrm{w} / \mathrm{w})$ and hydrogen peroxide $\left(\mathrm{H}_{2} \mathrm{O}_{2} 30 \% \mathrm{v} / \mathrm{v}\right)$. The products were isolated by filtration under vacuum after precipitation at $\mathrm{pH}$ between 1 and 3, as shown in Table I.

Yields ranged from 51 to $97 \%$. No significant difference was observed in the yields of the products upon varying the nature of the group or atom on the isatin ring (entries 1-11). In these cases, the reactions were left for $15 \mathrm{~min}$. under stirring at room temperature, whereas those of isatins containing a substituent on the nitrogen atom required longer reaction times for completion (45 min.) under the same reaction conditions. Good yields of the products were also obtained in these cases.

An advantage of this method is that it allows the synthesis of anthranilic acids containing ortho or metha substituents to the amino group (entries 7-8). Oxidation of isatin has also proven to be efficient for the preparation of disubstituted anthranilic acids (entries 9-11), prepared otherwise by electrophilic substitution on the aromatic ring. The method also allows the preparation of alkyl- (entries 13-16) or acyl- (entry 12) $N$-substituted anthranilic acids. It should be noted that $\mathrm{N}$-alkylation of isatins is a simple process (Wang et al. 2012, Garden et al. 1998), whereas anthranilic acid $N$-alkylation often requires drastic reaction conditions and the use of expensive catalysts (Hikawa and Yokoyama 2011).

TABLE I

Anthranilic acids obtained from isatin with their respective reaction times (in $\mathrm{min}$ ), $\mathrm{pH}$ and yields (\%).

Entry


TABLE I (continuation)

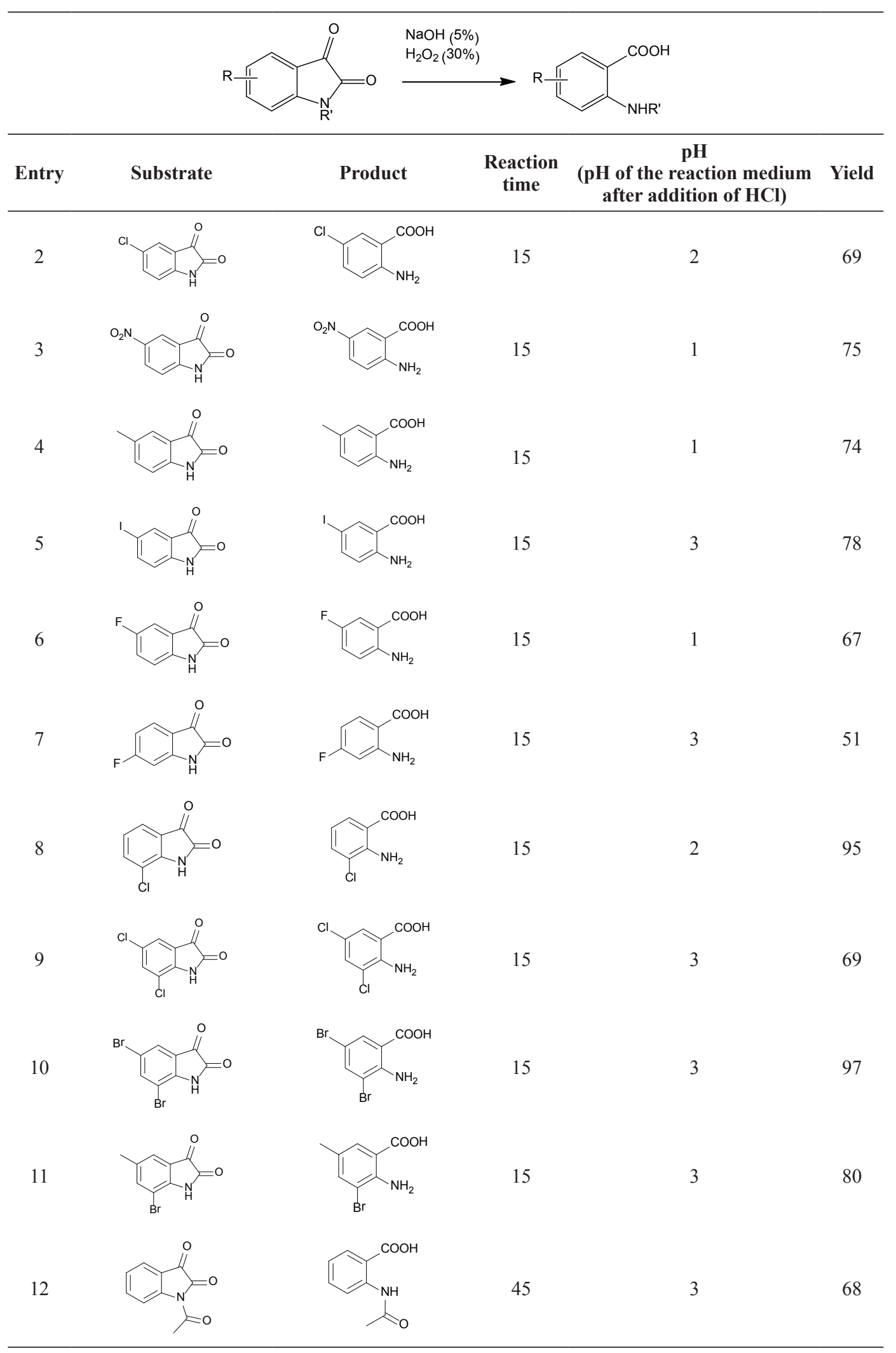


TABLE I (continuation)

\begin{tabular}{|c|c|c|c|c|c|}
\hline & & 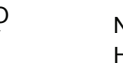 & & & \\
\hline Entry & Substrate & Product & $\begin{array}{c}\text { Reaction } \\
\text { time }\end{array}$ & $\begin{array}{c}\mathrm{pH} \\
\text { (pH of the reaction medium } \\
\text { after addition of } \mathrm{HCl} \text { ) }\end{array}$ & Yield \\
\hline 13 & & & 45 & 3 & 74 \\
\hline 14 & & & 45 & 3 & 91 \\
\hline 15 & & & 45 & 3 & 78 \\
\hline 16 & & & 45 & 3 & 91 \\
\hline
\end{tabular}

A mechanistic proposal for the isatin oxidation in the presence of $\mathrm{H}_{2} \mathrm{O}_{2}$ and $\mathrm{NaOH}$ is described in Scheme 1.

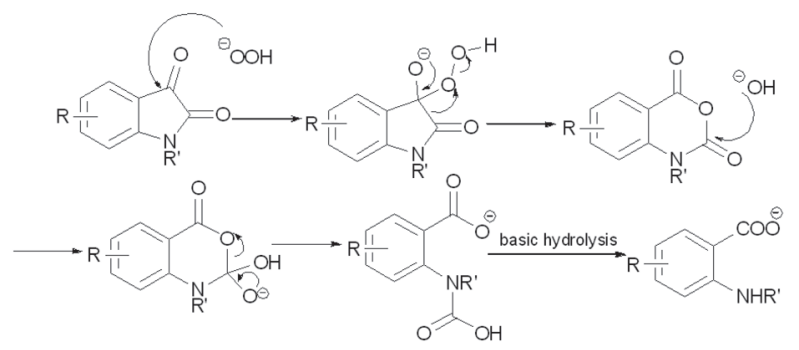

Scheme 1 - Mechanistic proposal for the isatin oxidation in the presence of $\mathrm{H}_{2} \mathrm{O}_{2}$ and $\mathrm{NaOH}$.

\section{CONCLUSION}

This work shows the generality of the isatin oxidation method for the preparation of anthranilic acids. The isatins used as starting materials may contain different substituents on the nitrogen atom or in the aromatic ring. This methodology offers the possibility to prepare different $N$-substituted anthranilic acids via simple alkylation and $\mathrm{N}$-acylation reactions. Furthermore, all the products are obtained in short reaction times without catalysts and using aqueous basic solutions, featuring an environmentally friendly method.

\section{ACKNOWLEDGMENTS}

The authors thank the Conselho Nacional de Desenvolvimento Científico e Tecnológico (CNPq), Fundação Carlos Chagas Filho de Amparo à Pesquisa do Estado do Rio de Janeiro (FAPERJ) and the Coordenação de Aperfeiçoamento de Pessoal de Nível Superior (CAPES) for supporting the research. 


\section{RESUMO}

Este artigo descreve a preparação de uma série de 16 ácidos antranílicos, em rendimentos que variaram de 51 a $97 \%$, através do tratamento de isatinas com $\mathrm{NaOH}$ e $\mathrm{H}_{2} \mathrm{O}_{2}$. Independentemente da natureza do substituinte no anel aromático, as reações se completaram em 15 min. a temperatura ambiente, ao passo que as isatinas contendo substituinte no átomo de nitrogênio requereram um tempo maior para completar a reação (45 min.), sob as mesmas condições.

Palavras-chave: isatina, ácido antranílico, ácido 2-aminobenzoico, oxidação da isatina.

\section{REFERENCES}

Chaudhuri SK, Roy S, SAHA M AND Bhar S. 2007. Regioselective aromatic electrophilic bromination with dioxane dibromide under solvent-free conditions. Synth Commun 37: 579-583.

DA Silva JM, GARden SJ ANd PINTO AC. 2001. The Chemistry of isatins: a review from 1975 to 1999. J Braz Chem Soc 12: $273-324$.

Garden SJ, Torres JC, Silva LE AND Pinto AC. 1998. A convenient methodology for the $\mathrm{N}$-alkylation of isatin compounds. Synth Commun 28: 1679-1689.

GÉRARD AL, LisowsKi V AND RAULT S. 2005. Direct synthesis of new arylanthranilic acids via a Suzuki cross-coupling reaction from iodoisatins. Tetrahedron 61: 6082-6087.

GuIN D, BARUWATI B AND MANORAMA SV. 2007. Pd on amineterminated ferrite nanoparticles: a complete magnetically recoverable facile catalyst for hydrogenation reactions. Org Lett 9: 1419-1421.

HIKAWA H AND YOKOYAMA Y. 2011. Palladium-catalyzed mono- $N$-allylation of unprotected anthranilic acids with allylic alcohols in aqueous media. J Org Chem 76: 84338439.

HoSANGADI BD AND DAVE RH. 1996. An efficient general method for esterification of aromatic carboxylic acids. Tetrahedron Lett 37: 6375-6378.

HuANG ST, HSEI IJ AND CHEN C. 2006. Synthesis and anticancer evaluation of bis(benzimidazoles), bis(benzoxazoles), and benzothiazoles. Bioorg Med Chem 14: 6106-6119.

LAHM GP ET AL. 2007. Rynaxypyr ${ }^{\text {TM}: ~ A ~ n e w ~ i n s e c t i c i d a l ~}$ anthranilic diamide that acts as a potent and selective ryanodine receptor activator. Bioorg Med Chem Lett 17: 6274-6279.

LisowSKI V, RoBBA M AND RAULT S. 2000. Efficient synthesis of novel 3-(het)arylanthranilic acids via a Suzuki crosscoupling reaction of 7-iodoisatin with (het)arylboronic acids in water. J Org Chem 65: 4193-4194.
MAHIWAL K, KUMAR P AND NARASIMHAN B. 2012. Synthesis, antimicrobial evaluation, ot-QSAR and mt-QSAR studies of 2-amino benzoic acid derivatives. Med Chem Res 21: 293-307.

MAYER F AND Schulze R. 1925. Über das 4- und 6-Methylisatin. Ber Dtsch Chem Ges 58: 1465-1469.

Mendoza JLH, Velásquez JDQ, MEdinA VRM AND PERÉz NM. 2008. Biosíntesis de ácido antranílico y ácido indolacético a partir de triptófano en una cepa de Azospirillum brasilense nativa de Tamaulipas. Avances en Investigación Agropecuária 12: 57-67.

NAik S, Bhattacharjya G, TAlukdar B and Patel BK. 2004. Chemoselective acylation of amines in aqueous media. Eur J Org Chem 2004: 1254-1260.

NitToli T ET AL. 2007. Identification of anthranilicacid derivatives as a novel class of allosteric inhibitors of hepatitis C NS5B polymerase. J Med Chem 50: 2108-2116.

PAJOR M AND SUN NN. 2013. Nonsteroidal anti-inflammatory drugs and other anthranilic acids inhibit the $\mathrm{Na}^{+}$ dicarboxylate symporter from Staphylococcus aureus. Biochemistry 52: 2924-2932.

PANDARUS V, CiRIMINNA R, BÉLANd F AND PAGLIARO M. 2011. Selective hydrogenation of functionalized nitroarenes under mild conditions. Catal Sci Technol 1: 1616-1623.

PopP PD. 1975. The chemistry of isatin. Adv Heterocycl Chem 18: $1-58$.

WANG Y AND OKABE N. 2005. Crystal structures and spectroscopic properties of zinc (II) ternary. Chem Pharm Bull 53: 645-652.

WANG Y, ZHANG M, CAO S, LIN H, GAO M AND Li Z. 2012. Synthesis of 1-substituted $4(1 \mathrm{H})$-quinazolinones under solvent-free conditions. Synth Commun 42: 2715-2727.

WiKLUND P AND BERGMAN J. 2004. Alkylation and acylation of basic salts of anthranilic acid. Tetrahedron Lett 45 : 969-972.

WikLund P AND BeRgman J. 2006. The chemistry of anthranilic acid. Curr Org Synth 3: 379-402.

XU H AND WOLF C. 2009. Efficient copper-catalyzed coupling of aryl chlorides, bromides and iodides with aqueous ammonia. Chem Commun 21: 3035-3037.

YADAV GD AND KRISHNAN MS. 1998. An ecofriendly catalytic route for the preparation of perfumery grade methyl anthranilate from anthranilic acid and methanol. Org Proc Res Dev 2: 86-95.

\section{SUPPLEMENTARY MATERIAL}

- NMR spectra $\left({ }^{1} \mathrm{H}\right.$ and $\left.{ }^{13} \mathrm{C}\right)$, infrared and the typical procedure for preparation of the compounds (Experimental section).

- Figures 1-48. 
